\title{
ANALISIS UMUR PIUTANG TERHADAP PENDAPATAN INDIHOME DI PT. TELKOM KOTA SORONG
}

\author{
1Hamdan Hidayat, ${ }^{2 *}$ Ramli Lewenussa, ${ }^{3}$ Bekti Wiji Lestari \\ Universitas Muhammadiyah Sorong, Indonesia \\ *ramlilewenussa@gmail.com
}

\begin{abstract}
Abstrak
Penelitian ini bertujuan untuk mengetahui apakah umur piutang berpengaruh terhadap pendapatan IndiHome di PT. Telkom kota Sorong. Penelitian ini menggunakan metode penelitian Deskriptif Kualitatif, dengan teknik analisis SWOT. Data primer penelitian ini diperoleh dengan menyebarkan kuesioner kepada responden dan di kumpulkan kembali, dengan menggunakan Matriks Bobot IFE dan EFE dan Matriks Rating IFE dan EFE untuk mengukur nilai dan di buat Matriks Kuadran supaya bisa mengetahui umur piutang terdapat pada kekuatan (strenght), kelemahan (weakness), peluang (opportunity), ancaman (Threat). Penelitian ini menyebarkan kuesioner kepada responden pegawai PT. Telkom kota Sorong dan Pelanggan IndiHome kota Sorong. Hasil responden pegawai PT. Telkom kota Sorong yaitu SWOT (IFE) mentukan pada kekuatan (strength) yang berada di kuadran I. Maka umur piutang terhadap pedapatan IndiHome di PT. Telkom kota Sorong untuk terhindar dari kelemahan perusahaan. Hasil SWOT (EFE) yaitu menentukan pada peluang (opportunity) yang berada di kuadran I. Maka dari kekuatan umur piutang bisa di jadikan peluang-peluang untuk PT. Telkom kota Sorong untuk terhindar dari umur piutang macet atau kredit.
\end{abstract}

Kata Kunci: Umur Piutang Dengan Menggunakan Analisis SWOT

\section{Abstract}

This study aims to determine whether the age of accounts receivable affects IndiHome income at PT. Telkom city of Sorong. This study uses a descriptive qualitative research method, with a SWOT analysis technique. The primary data of this study were obtained by distributing questionnaires to respondents and collecting them again, using the IFE and EFE Weight Matrix and the IFE and EFE Rating Matrices to measure values and creating a Quadrant Matrix so that you can find out the age of accounts receivable in strength (strength), weakness (weakness), opportunities (opportunity), threats (threat). This study distributed questionnaires to the respondents of PT. Telkom city of Sorong and IndiHome customers in Sorong city. Results of respondents of employees of PT. Telkom city of Sorong, namely SWOT (IFE) determines the strength (strength) in quadrant I. So the age of accounts receivable to IndiHome income at PT. Telkom city of Sorong to avoid company weakness. The result of SWOT (EFE) is to determine the opportunity (opportunity) that are in quadrant I. So from the strength of the age of accounts receivable can be used as opportunities for PT. Telkom city of Sorong to avoid bad debts or credit.

Keywords: Age of Accounts Receivable Using SWOT Analysis

\section{PENDAHULUAN}

Di era globalisasi saat ini, perkembangan teknologi sangatlah maju dan pesat. Secara langsung maupun tidak langsung menimbulkan dampak yang dominan dalam kegiatan sehari - hari. Teknologi merupakan salah satu peralatan modern yang memberikan alternatif pemecahan masalah yang efektif dalam memenuhi kebutuhan informasi. Selain itu teknologi merupakan alat yang memperlancarkan pertukaran informasi dan jaringan internet menyediakan informasi dan melakukan pengiriman data yang baik, gambar, suara yang tepat dan akurat. PT. Telekomunikasi (Persero) Tbk, merupakan salah satu perusahaan terbesar yang bergerak dibidang telekomunikasi, Berdasarkan Anggaran Dasar Perusahaan, ruang lingkup kegiatan Telkom Indonesia adalah menyelenggarakan jaringan dan jasa telekomunikasi, informatika, serta optimalisasi sumber daya perusahaan, dengan memperhatikan peraturan 
perundang-undangan yang berlaku. Kegiatan usaha utama Telkom Indonesia adalah menyediakan layanan telekomunikasi yang mencakup sambungan telepon kabel tidak bergerak dan telepon nirkabel tidak bergerak, komunikasi selular, layanan jaringan dan interkoneksi serta layanan internet dan komunikasi data. Selain itu, Telkom Indonesia juga menyediakan berbagai layanan di bidang informasi, media dan edutainment, termasuk cloud-based dan server-based managed services, layanan ePayment dan IT enabler, e-Commerce dan layanan portal lainnya. IndiHome merupakan perusahaan Telekomunikasi Indonesia milik PT. Telekomunikasi Indonesia. IndiHome mencakup 3 layanan biasa dikenal dengan Triple Play yaitu Internet On-Fiber / High Speed Internet, Telepon Rumah, Tv Interantif Milik UseeTV. Dahulu sebelum bernama IndiHome nama ISP ini adalah Speedy namun semenjak 2015 layanan Speedy dihentikan sejak di luncurkannya IndiHome dan pelanggan Speedy satu persatu diminta untuk beralih menggunakan IndiHome di karenakan layanan dihentikan pada tahun 2015.

PT. Telkom kota sorong yang bergerak di produk IndiHome merupakan perusahaan yang berkembang dan maju di kota sorong, di karenakan banyak masyarakat yang menggunakan internet di daerah yang belum terjangkau signal yang bagus. Maka PT. Telkom kota sorong menawarkan IndiHome supaya masyarakat yang daerahnya belum terjangkau signal yang bagus bisa menggunakan akses internet juga. IndiHome juga merupakan salah satu program dari proyek utama Telkom, indonesia digital Network 2015. Dalam penyelenggaraannya Telkom menggandeng sejumlah pengembang teknologi telekomunikasi untuk membangun rumah berkonsep digital. Pelayanan IndiHome hanya bisa diterapkan pada rumah yang di wilayahnya terdapat tersedia jaringan serat optik dari Telkom (FTTH) dan area yang masih menggunakan kabel tembaga. Lalu, pada 20 Mei, Telkom menghadirkan teknologi $4 \mathrm{~K}$ TV untuk
IPTV. Paket dan Layanannya Saat ini menyediakan beberapa paket layanan antara lain paket Single Play, Dual Play dan Triple Play. Single Play menyediakan koneksi Fiber Optik dengan layanan Internet dengan atau tanpa telepon rumah. Dual play menyediakan koneksi Fiber Optik dengan layanan internet dan telepon rumah atau internet dan iptv useetv. Triple Play menyediakan koneksi Fiber Optik dengan layanan internet, telepon rumah, dan IPTV UseeTV.

Menurut (Satori dan Komariyah, 2014:200) analisis adalah suatu usaha untuk mengurai suatu masalah atau fokus kajian menjadi bagian-bagian (decomposition) sehingga susunan/tatanan bentuk sesuatu yang diurai itu tampak dengan jelas dan karenanya bisa secara lebih terang ditangkap maknanya atau lebih jernih dimengerti duduk perkaranya.

Pengertian piutang menurut Soemarso (2004:338) merupakan kebiasaan bagi perusahaan untuk memberikan kelonggaran-kelonggaran kepada pelanggan pada waktu melakukan penjualan. Kelonggaran-kelonggaran yang diberikan biasanya dalam bentuk memperbolehkan para pelanggan tersebut membayar kemudian atau penjualan barang dan jasa yang dilakukan. Menurut Munandar (2006:77) piutang adalah tagihan perusahaan kepada pihak lain yang nantinya akan dimintakan pembayarannya bila mana telah sampai jatuh tempo.

Menurut Lam dan Lau (2014:317) pendapatan (revenue) adalah arus masuk bruto dari manfaat ekonomi selama periode berjalan yang muncul dalam rangkaian kegiatan biasa dari sebuah entitas ketika arus masuk dihasilkan dalam penambahan modal, selain yang berkaitan dengan kontribusi pemegang ekuitas. Menurut Ikatan Akuntan Indonesia (2005:23.1) pendapatan adalah penghasilan yang timbul dari hasil pelaksanaan aktivitas entitas yang normal dan dikenal dengan sebutan yang berbeda, seperti penjualan, penghasilan jasa, bunga, dividen, dan sewa.

PT. Telkom kota sorong yang mengelolah produk IndiHome memiliki 
pelanggan yang banyak di kota sorong. Yang mana pelanggannya membayar pemakaian IndiHome dengan secara Cash dan Kredit maka akan menimbulkan kesibukan pada karyawan dan bisa berimbas pada perusahaan tersebut. Berdasarkan uraian yang di paparkan diatas baik secara empiris maupun teoritis maka peneliti tertarik untuk melakukan penelitian dengan judul "Analisis Umur Piutang Terhadap Pendapatan Indihome Di PT. Telkom Kota Sorong". Temuan dari studi ini diharapkan memberikan tambahan pada literature yang ada dengan menyampaikan pemahaman dan manfaat tentang judul yang diambil dalam penyusunan Skripsi.

\section{TINJAUAN PUSTAKA}

1. Piutang

piutang menurut Soemarso (2004:338) merupakan kebiasaan bagi perusahaan untuk memberikan kelonggaran-kelonggaran kepada pelanggan pada waktu melakukan penjualan. Kelonggaran-kelonggaran yang diberikan biasanya dalam bentuk memperbolehkan para pelanggan tersebut membayar kemudian atau penjualan barang dan jasa yang dilakukan.

Analisis umur piutang menurut Indriyo Gitosudarmo (2010) merupakan suatu bentu laporan guna mengetahui posisi dengan melakukan pengelompokan piutang pada tertentu. Dengan mengelompokan tersebut manajemen perusahan dapat mengetahui posisi piutang sehingga dapat mengambil kebijakan keungan yang tepat. Kegunaan analisis umur piutang adalah alat bagi manajemen untuk mengambil kebijakan dalam pemberian kredit dan penagihan. Hal ini terutama dalam melakukan analisis piutang tak tertagih dengan mengelompokan piutang berasarkan umur.

2. Penggolongan Piutang

Piutang merupakan semua hak atau klaim terhadap pihak lain atas uang, barang atau jasa terhadap seseorang atau perusahaan lain atas penjualan kredit yang dilakukan. Soemarso (2010: 339) mengemukakan bahwa piutang diklasifikasikan sebagai piutang dagang dan piutang lain-lain. Piutang dapat meliputi piutang yang timbul karena penjualan produk atau penyerahan jasa dalam rangka kegiatan usaha norma perusahaan. Piutang yang timbul diluar kegiatan usaha normal perusahaan digolongkan dalam piutang lain-lain.

Berdasarkan uraian tersebut dapat disimpulkan bahwa piutang dapat diklasifikasikan menjadi dua (2) bagian besar, yaitu: Piutang Dagang dan Piutang Lain-lain.

\section{a. Piutang Dagang}

Piutang dagang merupakan piutang yang berasal dari penjualan barang-barang atau jasa yang dihasilkan perusahaan. Piutang ini merupakan penjualan kredit jangka pendek kepada pelanggan. Pembayarannya biasanya jatuh tempo 30-50 hari.

\section{b. Piutang lain-lain}

Menurut Smith (2009: 286) bahwa piutang lain meliputi saluran tipe piutang lainnya. Piutang lain-lain dari berbagai transaksi seperti:

1) Penjualan sekuritas atau harta benda lain selain persediaan

2) Uang muka kepada pemegang saham, para direktur, pejabat, dan karyawan

3) Setoran atau deposito kepada kreditor, perusahaan utilitas (Perum) dan instilasi instilasi lainnya

4) Pembayaran dimuka atas pembelian

5) Tuntutan atas kerugian dan kerusakan

6) Harga saham yang masih harus ditagih

7) Piutang deviden dan bunga

3. Biaya Atas Piutang

Menurut Gitosudarmo (2012: 82) adalah dengan dilaksanakannya penjualan secara kredit yang kemudia 
menimbulkan piutang maka perusahan sebenarnya tidak terlepas dari penanggungan resiko berupa biaya. Biaya yang timbul akibat adanya piutang yaitu:

a. Biaya penghapusan piutang

b. Biaya pengumpulan piutang

c. Biaya administrasi

d. Biaya sumber dana

4. Metode Cadangan Kerugian Piutang

Metode cadangan kerugian piutang ada dua, yaitu metode cadangan dan metode penghapusan langsung.

a. Metode Cadangan

Menurut Mardiasmo (2011: 96)

"metode cadangan adalah kerugian yang dijadikan akibat adanya piutang yang tidak dapat ditagih harus menjadi beban periode dimana keputusan pembelian kredit dilaksanankan".

b. Metode penghapusan langsung

Metode ini beranggapan bahwa kerugian piutang diakui dan dicatat menjadi beban jika tidak dapat ditagih. Piutang tidak dapat tertagih diperoleh setelah perusahaan mendapat pemberitahuan resmi bahwa debitur dinyatakan pailit oleh instansi yang berwenang atau pemberitahuan debitur sendiri bahwa yang bersangkutan tidak mampu lagi melunasi kewajibannya. Jadi perusahaan harus menghapus dengan mendebet rekening kerugian piutang sebagai pengurang akibat tidak tertagihnya piutang.

5. Perputaran Piutang dan Umur Piutang

a. Perputaran Piutang

Piutang yang dimiliki oleh suatu perusahaan mempunyai hubungan yang erat dengan volume penjualan kredit, karena timbulnya piutang disebabkan oleh penjualan barang-barang secara kredit dan hasil dari penjualan secara kredit netto dibagi dengan piutang rata-rata merupakan perputaran piutang.

b. Umur Piutang

Dyckman, Dukes dan Davis (2001:312) mengatakan bahwa pendekatan umur piutang mengkategorikan setiap piutang usaha menurut umurnya (aging schedule) dan menerapkan persentase kerugian penagihan historis terhadap setiap kategori umur untuk menentukan saldo akhir penyisihan yang diperlukan.

\section{METODE}

Penelitian ini dilaksanakan di PT. Telkom kota Sorong yang terletak di Jl. Ahmad Yani No. 16. Waktu Penelitian ini dilaksanakan selama kurang lebih 3 (tiga) bulan yang dimulai dari bulan Juni 2020 September 2020.

\section{HASIL DAN PEMBAHASAN}

1. Analisis SWOT

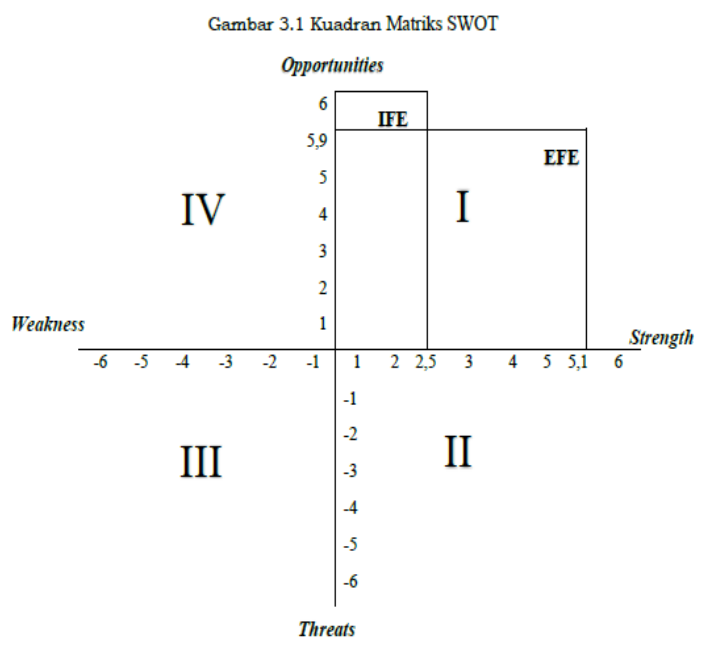

Gambar 1. Analisis SWOT

Pembahasan Kuadran Matriks SWOT:

a. Kuadran I bererti perusahaan harus meningkatkan penjualan produk supaya mendapatkan keuntungan yang sebesarnya.

b. Kuadran II bererti perusahan harus mengantisipasi datangnya persaingan dari manapun, maka perusahaan lebih sigap dalam menghadapi persaingan yang akan datang.

c. Kuadran III berarti perusahaan harus memperbaiki produk supaya tidak kalah bersaing dan bisa menembus pasar Internasional. 
d. Kuadran IV berarti perusahaan harus mengganti produk baru dan memulai dari awal.

e. Hasil SWOT IFE yaitu mentukan pada opprtunities dan strength yang berada di kuadran I. Maka dari kekuatan umur piutang bisa di jadikan peluang-peluang IndiHome di PT. Telkom kota Sorong untuk terhindar dari kelemahan perusahaan.

f. Hasil SWOT EFE yaitu menentukan pada opportunities dan strength yang berada di kuadran I. Maka dari kekuatan umur piutang bisa di jadikan peluang-peluang IndiHome di PT. Telkom kota Sorong untuk terhindar dari umur piutang macet atau kredit.

\section{Analisis Deskriptif Kualitatif}

a) Kualitas Pelayanan

Dapat dilihat berdasarkan frekuensi jawaban kualitas pelayanan bahwa tingkat kualitas pelayanan terhadap analisis SWOT umur piutang pada indikator, sangat tinggi. Ada 8 responden yang memiliki tingkat kualitas pelayanan yang tinggi. Hanya 1 responden yang memiliki kualitas pelayanan sedang, menunjukkan bahwa kualitas pelayanan sebagian besar responden adalah tinggi. Kualitas pelayanan yang tinggi ini dapat menjadi kekuatan dan peluang IndiHome di PT. Telkom kota Sorong.

b) Kepuasan Pelanggan

Dapat dilihat berdasarkan
frekuensi jawaban kepuasan
pelanggan bahwa tingkat kepuasan
pelanggan terhadap analisis SWOT
umur piutang pada indikator sangat
tinggi. Ada responden yang memiliki
tingkat kepuasan pelanggan yang
tinggi. Menunjukkanm bahwa
kepuasan pelanggan sebagian besar
responden adalah tinggi. Kepuasan
pelanggan yang tinggi ini dapat
menjadi kekuatan dan peluang
IndiHome di PT. Telkom kota Sorong.

Dari hasil responden di atas adalah untuk memperkuat hasil analisis SWOT, maka saya menggunakan kuesioner pelanggan dengan pernyataan kualitas pelayanan dan kepuasan pelanggan.

\section{PENUTUP \\ Kesimpulan}

Berdasarkan uraian pada bab-bab sebelumnya, dan dari hasil analisis serta pembahasan mengenai analisis umur piutang terhadap pendapatan indihome di PT. Telkom Sorong sebagai berikut :

1. Hasil SWOT IFE yaitu mentukan pada opprtunities dan strength yang berada di kuadran I. Maka dari kekuatan umur piutang bisa di jadikan peluang-peluang IndiHome di PT. Telkom kota Sorong untuk terhindar dari kelemahan perusahaan.

2. Hasil SWOT EFE yaitu menentukan pada opportunities dan strength yang berada di kuadran I. Maka dari kekuatan umur piutang bisa di jadikan peluangpeluang IndiHome di PT. Telkom kota Sorong untuk terhindar dari umur piutang macet atau kredit.

3. Dari hasil responden pelanggan adalah untuk memperkuat hasil analisis SWOT, maka saya menggunakan kuesioner pelanggan dengan pernyataan kualitas pelayanan dan kepuasan pelanggan. Dari hasil analisis deskriptif kualitas pelayanan sangat baik dan kepuasan pelanggan sangat nyama. Maka berpengaruh terhadap kekuatan dan peluang IndiHome di PT. Telkom kota Sorong.

\section{Saran}

1. Bagi Perusahaan: Berdasarkan hasil penelitian diketahui bahwa variable kualitas pelayanan ada 8 responden yang memiliki tingkat kualitas pelayanan yang tinggi dan 1 responden yang memiliki kualitas pelayanan sedang. Maka saran peneliti yaitu perusahaan lebih bersikap simpatik dan sanggup menenanggkan pelanggan setiap ada masalah. 
2. Bagi Peneliti: Yaitu dalam penelitian ini maka peneliti mengetahui umur piutang IndiHome di PT. Telkom kota Sorong. Tetapi dengan menggunakan analisis SWOT.

3. Penelitian Selanjutnya: Yaitu penelitian ini sebagai bahan pedoman untuk meneliti umur piutang terhadap perusahaan dengan menggunakan analisis SWOT. Jika penelitian susah atau terlambat mendapatkan data keuangan.

\section{DAFTAR PUSTAKA}

Aan Komariah, Djam'an Satori. 2014 Metodologi Penelitian Kualitatif. Bandung: Alfabeta.

Agus Harjito, Martono. 2008. Manajemen Keuangan, edisi1. yogyakarta: EKONISIA.

Amin, W. T. 1994. Manajemen Suatu Pengantar. Jakarta: Rineka Cipta.

Anwar, Z., Kahar, M. S., Rawi, R. D. P., Nurjannah, N., Suaib, H., \& Rosalina, F. (2020). Development of Interactive Video Based Powerpoint Media In Mathematics Learning. Journal of Educational Science and Technology (EST), 6(2), 167-177.

Arief Sugiono, 2009. "Panduan Praktis Dasar Analisa Laporan Keuangan". PT.Grasindo : Jakarta.

Baridwan, Zaki. 2000. Intermediate Accounting. Yogyakarta: BPFE.

Bintari, W. C., Rawi, R. D. P., \& Harisa, S. (2019). Pelatihan Penyusunan Laporan Keuangan Secara Sederhana Pada Mahasiswa Fakultas Ekonomi Universitas Muhammadiyah Sorong. Abdimas: Papua Journal of Community Service, 1(2), 6-13.

E. Kieso, Donald, Jerry J, Weygandt and Teery D. Warfield. (2011). Intermediate Accounting, Edisi 12. Jakarta: Erlangga.

Esterberg yang diterjemahkan Sugiyono. 2009. Memahami Penelitian Kualitatif. Bandung: Alfabeta.

Gitosudarmo, Indriyo dan Basri. 2012. Manajemen Keuangan. Edisi Keempat. Cetakan pertama. Yogyakarta:BPFE
Hanadelansa, H., \& Rawi, R. D. P. (2019). Analisis Audit Operasional Atas Pemberian Kredit Pemilikan Rumah Pada Pt Bank Rakyat Indonesia (Persero) Tbk Kantor Cabang Panakukkang Di Kota Makassar. SENTRALISASI, 8(1), 3342.

Haque, M. G., Nurjaya, N., Affandi, A., Erlangga, H., \& Sunarsi, D. (2021). Micro Financial Sharia Non-bank Strategic Analysis: a Study at BMT Beringharjo, Yogyakarta. Budapest International Research and Critics Institute (BIRCI-Journal): Humanities and Social Sciences, 4(2), 1677-1686.

Hasan, M. Iqbal, Pokok-pokok Materi Metodologi Penelitian dan Aplikasinya, Ghalia Indonesia, Bogor, 2002.

Hasan, M. Iqbal, Pokok-pokok Materi Metodologi Penelitian dan Aplikasinya, GhaliaIndonesia, Bogor, 2002.

Ikatan Akuntan Indonesia. 2015. Standar Akuntansi Keuangan. Jakarta: Ikatan Akuntan Indonesia.

Kamus Besar Bahasa Indonesia. 2005. Edisi Ketiga. Jakarta: Balai Pustaka.

Kieso, Donald E., Jerry J. Weygandt., \& Terry D. Warfield. (2012). Akuntansi Intermediate, edisi 12 jilid 1. Jakarta: Erlangga.

Lau, Peter dan Nelson, Lam. 2014. Akuntansi Keuangan (Intermediate Financial Reporting) Buku 1. Salemba Empat. Jakarta.

Lewenussa, R., Wijiastuti, R. D., \& Rawi, R. D. P. (2019). Pelatihan Fitur Project Dengan Sofware Accurate Pada Mahasiswa Program Studi Manajemen Dalam Rangka Peningkatan Produktifitas Dan Keterampilan Mahasiswa Dalam Dunia Kerja. Abdimas: Papua Journal of Community Service, 1(2), 31-44.

Munawir, S. 2010. Analisa Laporan Keuangan Edisi Keempat. Yogyakarta: Liberty.

Noryani, Y. B. G., Sari, W. I., Rosini, I., Munadjat, B., Sunarsi, D., \& Mahnun Mas' adi, G. (2020). Did ISO 45001, ISO 22000, ISO 14001 and ISO 9001 Influence Financial Performance? 
Evidence from Indonesian Industries. PalArch's Journal of Archaeology of Egypt/Egyptology, 17(7), 6930-6950.

P.Joko Subagyo. 2011.Metodologi Penelitian Dalam Teori Dan Praktek. Jakarta : Aneka Cipta.

Pujiati, H., Sunarsi, D., Affandi, A., \& Anggraeni, N. (2021). Effect of ISO 9001: 2015 Quality Management Implementation in Education on School Performance. Journal of Contemporary Issues in Business and Government, 27(1), 1848-1855.

Rangkuti, Freddy. 2001. Analisis SWOT Teknik Membedah Kasus Bisnis PT.Gramedia Pustaka Utama. Jakarta. Rangkuti, Freddy. 2001. Teknik Membedah Kasus Bisnis Analisis SWOT Cara Perhitungan Bobot, Rating, dan OCAI.
Penerbit PT. Gramedia Pustaka Utama. Jakarta.

Rawi, R. D. P., Lewenussa, R., \& Karmila, K. (2019). Pelatihan Pembuatan Keripik Pisang Sebagai Sarana Peluang Bisnis Dan Kreatifitas Mahasiswa Fakultas Ekonomi Universitas Muhammadiyah Sorong. Abdimas: Papua Journal of Community Service, 1(2), 24-30.

Santoso, Singgih. 2012. Statistik Parametik. Jakarta: PT Gramedia Pustaka Umum. Soemarso S.R, 2004, Akuntansi Suatu Pengantar, Edisi Lima, Salemba Empat, Jakarta.

Sugiyono. (2016). Metode Penelitian Kuantitatif, Kualitatif dan RED. Bandung: PT Alfabet. 